\title{
MENINGKATKAN LOYALITAS PELANGGAN BISNIS KULINER MELALUI INOVASI PRODUK DAN INOVASI PROSES
}

\author{
Hartelina ${ }^{(1)}$ \\ Hartelina.totoh@gmail.com ${ }^{(1)}$ \\ (1) Dosen Program Studi Manajemen- Universitas Singaperbangsa Karawang
}

\begin{abstract}
Ringkasan
Bisnis kuliner mengalami perkembangan yang sangat pesat. Tingkat persainganpun terjadi semakin ketat. Para pelaku bisnis kuliner berusaha untuk melakukan inovasi baik inovasi produk maupun inovasi proses untuk memastikan bisnisnya mampu bersaing. Tujuan penelitian ini adalah untuk mendapatkan bukti empiris mengenai pengaruh inovasi produk dan inovasi proses terhadap loyalitas pelanggan café dan restoran di Kota Bandung. Desain/Metode Penelitian menggunakan metode kuantitatif, dengan pendekatan verifikatif. Data dikumpulkan dengan kuesioner dengan respondennya adalah pelanggan café dan restoran. Data dianalisis dengan menggunakan multiple regression. Temuan penelitian mampu membuktikan bahwa secara empiris, inovasi produk dan inovasi proses berpengaruh signifikan terhadap loyalitas pelanggan. Begitu juga secara simultan, keduanya merupakan determinan yang signifikan. Sebagai implikasi dari hasil penelitian ini, sudah sewajarnya perusahaan café dan restoran menaruh perhatian besar pada upaya-upaya inovasi produk dan inovasi proses, guna meningkatkan loyalitas pelanggan. Selain itu perlu juga dikaji variable lain yang turut menentukan peningkatan loyalitas pelanggan.
\end{abstract}

Kata kunci: Inovasi produk, Inovasi proses, Loyalitas pelanggan.

\section{A. PENDAHULUAN}

Kota Bandung merupakan salah satu tujuan utama pariwisata. Sejak dibukanya Jalan Tol Cipularang, Kota Bandung telah menjadi tujuan utama dalam menikmati liburan akhir pekan terutama dari masyarakat yang berasal dari Jakarta dan sekitarnya. Salah satu bisnis yang merupakan daya dukung bagi perkembangan pariwisata di Kota Bandung adalah industry kuliner. Oleh karena itu, Bandung juga dikenal sebagai kota kuliner.

Salah satu jenis industry kuliner adalah café dan restoran. Saat ini, persaingan pada bisnis cafe dan restoran terjadi sangat ketat. Masing-masing melakukan berbagai upaya untuk menarik dan mempertahankan pelanggannya. Namun demikian, banyak juga cafe yang menawarkan produk sejenis dan pelayanan jasa yang serupa. Cafe-cafe dan restoran di Kota Bandung, umumnya mempunyai variasi menu yang berbeda-beda. Ada yang hanya menawarkan salah satu dari ketiga jenis menu seperti Asian food, European food dan Indonesian food dan adapula yang menawarkan ketiga jenis menu tersebut.

Berdasarkan pengamatan awal, secara garis besar para pelaku bisnis café umumnya melakua dua jenis inovasi dalam mempertahankan dan memikat pelanggan baru.
Kedua jenis inovasi tersebut adalah Inovasi Produk dan Inovasi Proses. Namun demikian, belum dapat dibuktikan bahwa kedua inovasi tersebut dapat meningkatkan loyalitas pelanggan.

Sehubungan dengan hal tersebut, penulis tertarik untuk melakukan analisis lebih lanjut, yakni mendapatkan bukti empiris pengaruh inovasi produk dan inovasi proses terhadap loyalitas pelanggan cafe di Kota Bandung. Hasil peneilitian ini diharapkan dapat menjadi pedoman awal untuk mengembangkan wisata, khususnya wisata kuliner di Kota Bandung.

\section{B. LANDASAN TEORI Inovasi}

Inovasi adalah pengenalan cara baru (pengenalan produk, proses atau sistem baru) dari cara-cara lama dalam mentransformasi input menjadi output sehingga menghasilkan perubahan besar dalam perbandingan antara nilai guna dan harga yang ditawarkan kepada konsumen dan/atau pengguna (Avanti, 2011:22). Inovasi harus berhasil menciptakan nilai (yang dipersepsikan konsumen) yang lebih tinggi daripada harga yang harus dibayar konsumen atau pembeli. Menurut Zangwill (1993) yang dikutip oleh Lena et al (2009:10), inovasi merupakan suatu hal yang sangat 
penting dalam mencapai keunggulan kompetitif. Tanpa inovasi, perusahaan akan mati. Dari definisi ini dapat dinyatakan bahwa perusahaan yang melakukan inovasi terus menerus akan dapat mendominasi pasar, dengan kreasi, model dan penampilan produk yang baru. Pada akhirnya dengan strategi inovasi akan memunculkan keunikan produk yang sulit ditiru pesaing.

Pengertian inovasi menurut Amabile (1996) yang dikutip oleh Titi laras (2012:41) bahwa inovasi sebagai penerapan hasil dari gagasan kreatif dalam perusahaan. Inovasi merupakan sebuah mekanisme perusahaan untuk beradaptasi dalam lingkungan yang dinamis. Oleh karena itu perusahaan dituntut untuk mampu menciptakan penilaian serta ideide yang baru dan menawarkan produk yang inovatif. Dari definisi ini dapat dinyatakan bahwa inovasi penting dilakukan perusahaan agar perusahaan dapat terus bertahan dalam persaingan bisnis yang ketat dengan memberikan sesuatu yang baru dimata konsumen.

Manfaat inovasi yang dikemukakan oleh Hendri (2009:15), yakni : 1). Peningkatan kualitas hidup manusia melalui penemuanpenemuan baru yang membantu dalam proses pemenuhan kebutuhan hidup manusia. Dari manfaat ini dapat dinyatakan bahwa dengan adanya inovasi dapat meningkatkan kualitas hidup manusia; 2). Memungkinkan suatu perusahaan untuk meningkatkan penjualan dan keuntungan yang dapat diperolehnya. Dari manfaat ini dapat dinyatakan bahwa perusahaan yang melakukan inovasi akan mendapat keuntungan. Diperkuat dengan definisi menurut Lukas \& Freel (2000) yang dikutip oleh Eddi (2009:37) inovasi produk adalah proses memperkenalkan teknologi baru yang digunakan. Hasil proses ini adalah pengenalan produk atau jasa baru yang dapat dijadikan sebagai alat untuk memperoleh keuntungan bagi perusahaan; 3). Adanya peningkatan dalam kemampuan mendistribusikan kreativitas kedalam wadah penciptaan sesuatu hal yang baru. Dari manfaat ini dapat dinyatakan bahwa inovasi menunjukkan peningkatan kreativitas yang diperkuat dengan definisi menurut Amabile (1996) yang dikutip oleh Titi laras (2012:41) mengatakan bahwa inovasi sebagai penerapan hasil dari gagasan kreatif dalam perusahaan; 4). Adanya keanekaragaman produk dan jenisnya didalam pasar. Dari manfaat ini dapat dinyatakan bahwa inovasi menciptakan keanekaragaman produk yang diperkuat dengan definisi menurut Inovasi produk menurut Avanti (2011:142), merupakan perubahan dalam bungkus produk, ukuran produk atau model produk dan warna produk.

Studi yang dilakukan oleh Carmen OteroNeira, Martti Tapio Lindman, Maria J. Fernandez (2008) menunjukkan beberapa bukti bahwa inovasi berpengaruh positif terhadap kinerja bisnis. Secara khusus, hasil menunjukkan bahwa tingkat kinerja yang berbeda terkait dengan jenis inovasi yang dikembangkan. Studi lain dilakukan oleh Tessa Avermaete, Jacques Viaene, Eleanor J. Morgan, Nick Crawford (2003) menemukan Inovasi dianggap penting oleh UKM yang cenderung untuk terus memperkenalkan produk baru, pengembangan proses baru, membuat perubahan dalam struktur organisasi dan mengekplorasi pasar baru. Inovasi tergantung pada umur perusahaan, ukuran perusahaan dan kinerja ekonomi regional

Ilker Murat Ar dan Birdogan Baki (2011:172), menyatakan bahwa adanya bukti empiris dari UKM yang berlokasi di taman ilmu pengetahuan dan teknologi Turki, inovasi produk dan proses memiliki hubungan yang kuat dan positif dengan kinerja perusahaan. Menurut Mone et al. (1998) yang dikutip oleh llker Murat Ar dan Birdogan Baki (2011:181), kemampuan inovasi perusahaan merupakan bagian penting dari kinerja bisnis. Selain itu, perusahaan yang inovatif harus memiliki kinerja lebih tinggi dari non-perusahaan yang inovatif sesuai dengan Cozzarin (2004). Oleh karena itu, sejumlah besar akademisi telah meneliti hubungan antara inovasi dengan kinerja bisnis.

Studi Deshpande et al. (1993) yang dikutip oleh Ilker Murat Ar dan Birdogan Baki (2011:181), pada perusahaan-perusahaan Jepang menunjukkan bahwa inovasi adalah positif terkait dengan kinerja organisasi. Baldwin dan Johnson (1996) yang dikutip oleh Ilker Murat Ar dan Birdogan Baki (2011:181), menunjukkan bahwa ada dampak signifikan dari inovasi terhadap kinerja bisnis dilakukan pada perusahaan-perusahaan Kanada.

\section{Inovasi Produk}

Menurut Lukas \& Freel (2000) yang dikutip oleh Eddi (2009:37), inovasi produk adalah proses memperkenalkan teknologi baru yang digunakan. Hasil proses ini adalah pengenalan produk atau jasa baru yang dapat dijadikan sebagai alat untuk memperoleh keuntungan bagi perusahaan. Dari definisi ini dapat dinyatakan bahwa inovasi produk lebih ditekankan pada teknologi baru yang digunakan perusahaan. Dengan produk baru inilah perusahaan menjadikannya sebagai umpan untuk memperoleh keuntungan bagi perusahaan. 
Inovasi produk menurut Lena dan Lina (2009:37) merupakan hasil dari penciptaan dan pengenalan produk secara radikal atau modifikasi produk yang telah ada. Dari definisi ini dapat dinyatakan bahwa inovasi produk dapat dilakukan secara keselurahan maupun dengan memodifikasi produk yang sudah ada. Dengan kata lain, perusahaan dituntut untuk melakukan perubahan pada produk agar konsumen tidak merasa jenuh terhadap produk tersebut.

Inovasi produk menurut Avanti (2011:142), merupakan perubahan dalam bungkus produk, ukuran produk atau model produk dan warna produk. Dari definisi ini dapat dinyatakan bahwa perusahaan dituntut untuk melakukan inovasi produk yang lebih menekankan pada perubahan produk secara keseluruhan terkait dengan produk tersebut.

Dari definisi tentang inovasi produk diatas, peneliti dapat menyatakan bahwa pentingnya inovasi produk untuk dapat bertahan dalam persaingan bisnis karena inovasi produk merupakan alat bagi perusahaan untuk mendapatkan keuntungan. Perusahaan dapat melakukan inovasi produk dengan cara melakukan perubahan secara total pada produk, membuat produk baru dan dapat dengan menggunakan teknologi baru, yang sesuai dengan kebutuhan pelanggan. Dengan adanya inovasi produk yang dilakukan oleh perusahaan, maka konsumen tidak akan jenuh dengan produk yang ditawarkan oleh perusahaan jika produk yang ditawarkan tersebut mempunyai manfaat dan nilai dimata konsumen. Inovasi produk harus dilakukan secara berkelanjutan karena persaingan bisnis tidak pernah berhenti, maka dari itu strategi perusahaan dalam meningkatkan inovasi produkpun tidak boleh berhenti.

\section{Inovasi Proses}

Menurut Cumming (1998) yang dikutip oleh Carmen et al (2009:218), Inovasi proses mencakup rekayasa ulang proses bisnis, peningkatan operasi internal dan kapasitas. Pentingnya inovasi proses cukup dipahami dengan baik, terutama di perusahaanperusahaan di bawah ancaman karena dapat membantu untuk meningkatkan produktivitas perusahaan. Dari definisi ini dapat dinyatakan bahwa perusahaan harus melakukan inovasi proses seperti merekayasa ulang proses bisnis, peningkatan operasi internal dan kapasitas yang akan berdampak pada produktivitas perusahaan.

Inovasi proses adalah menekankan pada metode-metode baru dalam pengoperasian dengan cara membuat teknologi baru atau mengembangkan teknologi yang sudah ada.
Dari definisi ini dapat dinyatakan bahwa inovasi proses lebih kepada teknologi yang digunakan oleh perusahan. Perusahaan dituntut untuk membuat teknologi baru atau mengembangkan teknologi yang sudah ada. (Lena dan Lina, 2011:37). Pendapat lainnya, menurut Touminien \& Havynen (2004) yang dikutip oleh Eddi (2009:36), inovasi proses adalah proses peningkatan atau pembaharuan metode produksi yang akan mendorong pengurangan dalam unit, biaya dan waktu produksi. Dari definisi ini dapat dinyatakan bahwa inovasi proses lebih ditekankan pada metode produksi. Perusahaan dituntut untuk mengembangkan metode produksi yang sudah ada, dengan adanya pembaharuan metode produksi maka akan meningkatkan efisiensi atau efektivitas dalam melakukan proses produksi.

Dari definisi tentang inovasi proses diatas, peneliti dapat menyatakan bahwa pentingnya inovasi proses untuk dapat bertahan dalam persaingan bisnis karena inovasi proses akan berdampak pada produktivitas perusahaan yang berarti dapat menguntungkan perusahaan. Perusahaan dituntut untuk melakukan inovasi proses seperti merekayasa ulang proses bisnis, mengembangkan teknologi yang sudah ada atau membuat teknologi baru yang akan meningkatkan efisiensi atau efektivitas dalam melakukan proses produksi, karena semakin efisien proses produksi maka akan berdampak pada biaya yang semakin rendah.

\section{METODE PENELITIAN}

Desain penelitian ini adalah penelitian verifikatif untuk menguji hubungan kausalitas antara Inovasi prduk dan Inovasi proses terhadap Loyalitas pelanggan. Pendekatannya adalah kuantitatif. Indikator inovasi mengacu pada llker Murat Ar dan Birdogan Baki (2011:206), yakni : Inovasi produk (Menjadi Cafe Dengan Inovasi Produk Tertinggi, Menggambarkan Diri Sebagai Cafe Yang Fokus Pada Inovasi Produk; Produk dan Layanan Cafe Terbaru). Inovasi Proses (Menjadi Café Dengan Inovasi Proses Tertinggi, Menggambarkan Diri Sebagai Cafe Yang Fokus Pada Inovasi Proses; Inovasi Proses Terbaru).

Data dikumpulkan dengan kuesioner, dimana respondennya adalah para pelanggan pengunjung café. Sampel ditentukan dengan metode simple random sampling. Jumlah sampel ditentukan dengan teknik iterasi. Analisis data dilakukan menggunakan multiple regression. 


\section{HASIL DAN PEMBAHASAN}

Pada bagian ini akan dijelaskan mengenai hasil analisis data dengan menggunakan Model regressi berganda (multiple regression). Berdasarkan hasil pengolahan data diperoleh hasil regressi sebagai berikut.:

Tabel 1.

Koefisien Regressi

Coefficients $^{\mathrm{a}}$

\begin{tabular}{|c|c|c|c|c|c|c|}
\hline \multirow{2}{*}{\multicolumn{2}{|c|}{ Model }} & \multicolumn{2}{|c|}{$\begin{array}{c}\text { Unstandardized } \\
\text { Coefficients }\end{array}$} & \multirow{2}{*}{$\begin{array}{c}\text { Standardized } \\
\text { Coefficients }\end{array}$} & \multirow[b]{2}{*}{$\mathrm{t}$} & \multirow[b]{2}{*}{ Sig. } \\
\hline & & $\mathrm{B}$ & Std. Error & & & \\
\hline \multirow[t]{3}{*}{1} & (Constant) & 2.023 & .308 & & 6.575 & .000 \\
\hline & Inovasi Produk & .323 & .094 & .447 & 3.445 & .001 \\
\hline & Inovasi Proses & 201 & .082 & .319 & 2.457 & .017 \\
\hline
\end{tabular}

a. Dependent Variable: Kinerja

Koefisien regresi inovasi produk bertanda positif sebesar 0.323 menunjukkan bahwa peningkatan inovasi produk sebesar satu satuan nilai akan meningkatkan loyalitas pelanggan sebesar $32.3 \%$. demikian juga dengan koefisien regresi inovasi proses bertanda positif sebesar 0.201 yang menunjukkan bahwa peningkatan inovasi proses sebesar satu satuan nilai diprediksi akan meningkatkan loyalitas pelanggan sebesar $20.1 \%$.

Sementara itu, nilai koefisien determinasi dapat dilihat pada tabel 2. Nilai R sebesar 0,695 pada tabel tersebut menunjukkan kekuatan hubungan kedua variabel independen (inovasi produk dan inovasi proses) secara simultan dengan loyalitas pelanggan. Kemudian, nilai RSquare sebesar 0,483 atau 48,3 persen menunjukkan bahwa kapabilitas inovasi yang terdiri dari inovasi produk dan inovasi proses secara simultan mampu menerangkan perubahan yang terjadi pada loyalitas pelanggan sebesar 48,3 persen. Artinya secara bersama-sama kedua variabel independen (inovasi produk dan inovasi proses) memberikan kontribusi atau pengaruh sebesar $48,3 \%$. Sisanya pengaruh faktor-faktor lain yang tidak diteliti adalah sebesar 51,7\%, yaitu merupakan pengaruh faktor lain diluar inovasi produk dan inovasi proses

Tabel 2.

Koefisien Determinasi

Model Summary
\begin{tabular}{|l|c|c|c|c|}
\hline Model & $\mathrm{R}$ & $\mathrm{R}$ Square & $\begin{array}{c}\text { Adjusted } \\
\text { R Square }\end{array}$ & $\begin{array}{c}\text { Std. Error of } \\
\text { the Estimate }\end{array}$ \\
\hline 1 & $.695^{\mathrm{a}}$ & .483 & .463 & .33794 \\
\hline
\end{tabular}
a. Predictors: (Constant), Inovasi Proses, Inovasi Produk
b. Dependent Variable: Kinerja

Selanjutnya untuk menguji apakah kapabilitas inovasi yang terdiri dari inovasi produk dan inovasi proses berpengaruh signifikan terhadap kinerja perusahaan, baik secara bersama-sama (simultan) maupun secara parsial (individual), maka dilakukan uji signifikansi. Pengujian dimulai dari pengujian simultan, dan apabila hasil pengujian simultan signifikan dilanjutkan dengan uji secara parsial.

Untuk menguji hipotesis pengaruh simultan digunakan statistik uji-F yang diperoleh melalui tabel anova seperti yang tertera pada tabel 3.

Berdasarkan tabel anova di atas dapat dilihat nilai $F_{\text {hitung }}$ hasil pengolahan data sebesar 24,290 dengan nilai signifikansi $<0,001$. Dari tabel $F$ pada $\alpha=0.05$ dan derajat bebas (2:52) diperoleh nilai $F_{\text {tabel }}$ sebesar 3,175 . Karena $F_{\text {hitung }}(24,290)$ lebih besar dari $F_{\text {tabel }}(3,175)$ maka pada tingkat kekeliruan 5\% ( $\alpha=0.05)$ dengan tingkat kepercayaan $95 \%$ dapat disimpulkan bahwa inovasi produk dan inovasi proses secara bersama-sama (simultan) 
berpengaruh signifikan terhadap loyalitas pelanggan.

Tabel 3.

Anova Untuk Pengujian Secara Simultan

ANOVA

\begin{tabular}{|rl|r|r|r|r|r|}
\hline \multicolumn{1}{|c|}{} & $\begin{array}{c}\text { Sum of } \\
\text { Model }\end{array}$ & Squares & df & Mean Square & F & Sig. \\
\hline 1 & Regression & 5.548 & 2 & 2.774 & 24.290 & $.000^{\mathrm{a}}$ \\
& Residual & 5.939 & 52 & .114 & & \\
& Total & 11.487 & 54 & & & \\
\hline
\end{tabular}

a. Predictors: (Constant), Inovasi Proses, Inovasi Produk

b. Dependent V ariable: Kinerja

Selanjutnya dilakukan pengujian signifikansi pengaruh parsial dengan uji t. nilai $t_{\text {hitung }}$ untuk masing-masing variabel independen sebagai berikut. Berdasarkan hasil pengolahan data diperoleh

Tabel 4

Nilai $t_{\text {hitung }}$ Masing-Masing Variabel Independen

Coefficients $^{\mathrm{a}}$

\begin{tabular}{|c|c|c|c|c|c|c|}
\hline \multirow[b]{2}{*}{ Mod } & & \multicolumn{2}{|c|}{$\begin{array}{c}\text { Unstandardized } \\
\text { Coefficients }\end{array}$} & \multirow{2}{*}{$\begin{array}{c}\begin{array}{c}\text { Standardized } \\
\text { Coefficients }\end{array} \\
\text { Beta }\end{array}$} & \multirow[b]{2}{*}{$\mathrm{t}$} & \multirow[b]{2}{*}{ Sig. } \\
\hline & & $\mathrm{B}$ & Std. Error & & & \\
\hline \multirow[t]{3}{*}{1} & (Constant) & 2.023 & .308 & & 6.575 & .000 \\
\hline & Inovasi Produk & .323 & .094 & .447 & 3.445 & .001 \\
\hline & Inovasi Proses & 201 & .082 & .319 & 2.457 & .017 \\
\hline
\end{tabular}

a. Dependent Variable: Kinerja

Nilai tabel yang digunakan sebagai nilai kritis pada uji parsial (uji t) sebesar 2,007 yang diperoleh dari tabel t pada $\alpha=0.05$ dan derajat bebas 52 untuk pengujian dua arah. Untuk nilai $t_{\text {hitung }}$ variabel inovasi produk, sebesar 3,445 dengan nilai signifikansi sebesar 0,001. Karena nilai $t_{\text {hitung }}(3,445)$ lebih besar dari $t_{\text {tabel }}(2,007)$ maka pada tingkat kekeliruan $5 \%$ sehingga disimpulkan bahwa inovasi produk berpengaruh signifikan terhadap loyalitas pelanggan. Hasil penelitian ini memberikan bukti empiris bahwa semakin baik inovasi produk akan meningkatkan loyalitas pelanggan.

Nilai $t_{\text {hitung }}$ variabel inovasi proses sebesar 2,457 dengan nilai signifikansi sebesar 0,017. Karena nilai $t_{\text {hitung }}(2,457)$ lebih besar dari $t_{\text {tabel }}$ $(2,007)$ maka pada tingkat kekeliruan 5\% disimpulkan bahwa inovasi proses memiliki pengaruh yang signifikan terhadap loyalitas pelanggan. Hasil penelitian ini memberikan bukti empiris bahwa semakin baik inovasi proses akan meningkatkan loyalitas pelanggan.

Hasil penelitian ini sesuai dengan Prajogo dan Ahmed dalam Murat \& Baki
(2011:182), menyatakan fakta bahwa ada hubungan positif antara inovasi dan kinerja bisnis. Dan hasil penelitian ini juga mendukung Lukas \& Freel (2000) dalam eddi (2009:37) bahwa inovasi produk adalah proses memperkenalkan teknologi baru yang digunakan. Hasil proses ini adalah pengenalan produk atau jasa baru yang dapat dijadikan sebagai alat untuk memperoleh keuntungan bagi perusahaan. Dari definisi ini dapat dinyatakan bahwa inovasi produk lebih ditekankan pada teknologi baru yang digunakan perusahaan. Dengan produk baru inilah perusahaan menjadikannya sebagai umpan untuk memperoleh keuntungan bagi perusahaan.

Hasil penelitian ini bersesuaian dengan temuan llker Murat Ar dan Birdogan Baki (2011:182) yang menyatakan bahwa kedua inovasi produk dan proses memiliki hubungan yang kuat dan positif dengan kinerja perusahaan. Dan hasil penelitian ini didukung dengan teori menurut Cumming (1998) dalam Carmen et.al (2008:218), menyatakan inovasi proses mencakup rekayasa ulang proses bisnis, 
peningkatan operasi internal dan kapasitas. Pentingnya inovasi proses cukup dipahami dengan baik, terutama di perusahaanperusahaan di bawah ancaman karena dapat membantu untuk meningkatkan produktivitas perusahaan. Dari definisi ini dapat dinyatakan bahwa perusahaan harus melakukan inovasi proses seperti merekayasa ulang proses bisnis, peningkatan operasi internal dan kapasitas yang akan berdampak pada produktivitas perusahaan dan kinerja perusahaan.

Menurut Dermawan Wibisono (2011:217), menyatakan bahwa pengukuran tingkat keberhasilan inovasi merupakan ukuran yang penting bagi kemampuan inovasi suatu organisasi dan efektivitas pengembangan teknologi serta proses pelaksanaannya dan inovasi memberikan dampak positif terhadap bisnis.

Hasil penelitian ini memberikan bukti empiris bahwa inovasi produk yang baik serta inovasi proses yang baik akan meningkatkan loyalitas pelanggant. Hasil penelitian ini didukung oleh Carmen Otero-Neira, Martti Tapio Lindman, Maria J. Ferna'ndez (2008:216), yang menyatakan beberapa bukti bahwa inovasi berpengaruh positif terhadap kinerja bisnis. Secara khusus, hasil menunjukkan bahwa tingkat kinerja yang berbeda terkait dengan jenis inovasi yang dikembangkan. Dan hasil penelitian menurut Mone et al. (1998) dalam Ilker Murat Ar dan Birdogan Baki (2011:181), kemampuan inovasi perusahaan merupakan bagian penting dari kinerja bisnis. Selain itu, perusahaan yang inovatif harus memiliki kinerja lebih tinggi dari non-perusahaan yang inovatif sesuai dengan Cozzarin (2004) dalam Murat dan Baki (2011:181)Dan hasil penelitian ini didukung dengan teori menurut Veithzal (2009) dalam titi laras (2012: 66), menyatakan kinerja adalah suatu tampilan keadaan secara utuh atas perusahaan selama periode waktu tertentu, merupakan hasil atau prestasi yang dipengaruhi oleh kegiatan operasional perusahaan dalam memanfaatkan sumbersumber daya yang dimiliki. Dari definisi ini dapat dinyatakan bahwa kinerja perusahaan adalah keberhasilan perusahaan yang dipengaruhi oleh kegiatan operasional perusahaan dalam sumber-sumber daya yang dimiliki.

\section{E. PENUTUP}

Secara empiris telah dapat dibuktikan, bahwa inovasi produk dan inovasi proses berpanguh signifikan terhadap Loyalitas pelanggan. Namun demikian studi ini belum sepenuhnya mampu mengungkapkan secara sempurna seluruh factor-faktor yang mempengaruhi loyalitas pelanggan café dan restoran. Hal ini tercermin dari nilai koefisien determinasi yang masih dibawah 50\%. Ini menunjukan bahwa masih banyak factor lain yang perlu dieksplorasi. Hal ini merupakan tantangan bagi penelitian berikutnya.

Selain itu, perlu juga dilakukan analisa lebbih lanjut mengenai bentuk-bentuk inovasi yang dilakukan secara lebih terperinci. Artinya, jenis-jen is inovasi produk dan inovasi proses seperti apa yang dilakukan, perlu lebih di berikan penjelasan secara mendalam. Hal ini akan dapat membantu para praktisi bisnis café dan restoran untuk dapat menjadikannya sebagai tambahan bekal pengetahuan untuk diterapkan pada perusahaannya masingmasing.

\section{F. DAFTAR PUSTAKA}

1. Asri Laksmi.2011. Budaya Organisasi. Yogyakarta : Graha IImu.

2. Avanti Fontana. 2011. Innovate we can. Manajemen Inovasi dan Penciptaan Nilai Individu, Organisasi, Masyarakat. Cetakan ketiga, Jakarta : Cipta Inovasi Sejahtera.

3. Carmen. Martti \& Maria. 2009. Innovation and performance in SME furniture industries. An international comparative case study. Marketing Intelligence \& Planning, vol. 27, no. 2, pp. 216-232.

4. Cooper, C. R., \& Schindler, P. S. (2008). Business research methods (10 ed.). Boston: McGraw-Hill.

5. Cozzarin, B. (2004), "Innovation quality and manufacturing firms' performance in Canada", Economics of Innovation and New Technology, Vol. 13 No. 3, pp. 199-216.

6. Damodar N. Gujarati, 2003 "Basic Econometrics" fourth edition McGraw-Hill, New York.

7. Dermawan Wibisono. 2011. Manajemen Kinerja Korporasi Dan Organisasi. Panduan Penyusunan Indikator. Penerbit Erlangga.

8. Eddi suprayitno, 2009, pengaruh orientasi pasar dan kapabilitas inovasi dalam meningkatkan nilai pelanggan serta dampaknya terhadap keunggulan bersaing.

9. Hartelina. 2010. Orientasi Pasar Dan Inovasi Organisasi Dalam Meningkatkan Pangsa Pasar Serta Implikasinya Pada Profitabilitas, Universitas Padjajaran. Bandung.

10.Imam Ghozali. 2005. Aplikasi Analisis Multivariate dengan Program SPSS. Semarang : Penerbit Universitas Diponogoro.

11.Lena Ellitan \& Lina Anatan. 2009. Manajemen Inovasi. Transformasi Menuju Organisasi Kelas Dunia. Bandung : Alfabeta.

12. Murat Ar \& Baki. 2011. Antecedents and performance impacts of product versus process innovation. Empirical evidence from 
SMEs located in Turkish science and technology parks. European Journal of Innovation Management Vol. 14 No. 2, pp. 172-206.

13.Nguyen. 2011. The WTO, marketing and innovativeness capabilities of Vietnamese firms. Management Research Review Vol. 34 No. 6, 2011 pp. 712-726.

14.Pabundu Tika. 2005. Budaya Organisasi Dan Peningkatan Kinerja Perusahaan. Jakarta : PT. Bumi Aksara

15.Singgih Santoso 2002, "Mengolah Data Statistik Secara Profesional' PT Elex Media Komputindo, Jakarta.

16.Sugiyono. 2000. Metode Penelitian Administrasi. Cetakan ke-tujuh. Bandung : Penerbit Alfabeta.

17. Tessa, Jacques, Morgan, Crawford. 2003. "Determinants of innovation in small food firms". European Journal of Innovation Management, Vol. 6 Iss: 1 pp. $8-17$.

18. Titi laras. 2012. Pengaruh Kreativitas dan Inovasi Terhadap Keunggulan Bersaing Serta Dampaknya Pada Kinerja Perusahaan (survei pada industri kreatif di kota Bandung), Universitas Padjadjaran. Bandung.

19.M.L. Santos-Vijande, L.I. A'Ivarez-Gonza'lez. 2007. Innovativeness and organizational innovation in total quality oriented firms: The moderating role of market turbulence.

Catatan :

Artikel ini telah dipresentasikan dalam Festival Riset IImiah Manajemen dan Akuntansi Tahun 2018 (FRIMA 2018) yang diselenggarakan Oleh STIE STEMBI - Bandung Business School, dan abstraknya dimuat dalam Prosiding FRIMA 2018 dengan ISSN No 2614-6681. Selanjutnya, Penulis melakukan beberapa revisi terhadap artikel ini untuk menyempurnakan isi dan kedalaman pembahasan, untuk dapat diterbitkan dalam jurnal INTEKNA. 